Nowoczesne Systemy Zarządzania

Zeszyt 16 (2021), nr 2 (kwiecień-czerwiec)

ISSN 1896-9380, s. 39-47

DOI: $10.37055 /$ nsz/139359

Modern Management Systems

Volume 16 (2021), No. 2 (April-June)

ISSN 1896-9380, pp. 39-47

DOI: $10.37055 / \mathrm{nsz} / 139359$
Instytut Organizacji i Zarządzania Wydział Bezpieczeństwa, Logistyki i Zarządzania

Wojskowa Akademia Techniczna

w Warszawie

Institute of Organization and Management Faculty of Security, Logistics and Management Military University of Technology

in Warsaw

\title{
Virtualization and cloud computing versus organization management in the realities of Industry 4.0
}

\section{Wirtualizacja i chmura obliczeniowa a zarządzanie organizacją w realiach Przemysłu 4.0}

\author{
Michał Jurek \\ Military University of Technology, Faculty of Security, Logistics and Management \\ michal.jurek@wat.edu.pl; ORCID: 0000-0003-0949-7458
}

\section{Martynas Gelgotas}

Business and Rural Development Research Institute, Vytautas Magnus University, Kaunas, Lithuania ORCID: 0000-0002-3990-9372

\begin{abstract}
Abstrakt. In a world of rapidly advancing digitalization and digitization and related amenities, organizations have begun to transfer their activities to the digital sphere. This allowed creation of a new concept - Industry 4.0, the main assumption of which is the networking of all activities taking place in enterprises. The main role in this process will be played by the possibility of virtualization (e.g. computer hardware) and access to it from any place at any time by stakeholders (clients, employees and other external entities) through an integrated environment ensuring adequate computing power (cloud computing). This phenomenon will generate new technical and technological solutions in the field of broadly understood automation of management processes. The issues discussed are particularly applicable in the event of various types of threats (external and internal), the emergence of which leads to the inability to physically (personally) run a business. This is particularly evident in the context of the recent events related to the outbreak of the coronavirus pandemic (SARS-CoV-2), which forced many entities (private and public) to switch to the remote work model. In order for it to fulfill its primary goal - ensuring the continuity of the entity's operation - new tools were created and existing tools were expanded, supporting remote work, which are also based on the virtualization of hardware resources and cloud computing. In order to reduce the level of risk, which has increased due to the need to quickly adapt the processes taking place in organizations to the formula of remote work (increased occurrence of cyber threats), it becomes necessary to
\end{abstract}


analyze the available tools in order to prepare appropriate recommendations (good practices) that can be implemented in any public or private entity (organization). For this purpose, it is necessary to analyze the background data (desk research) and review the available literature on the subject (including the available technical documentation) in order to obtain a catalog of effective technical and organizational solutions. Keywords: virtualization, cloud computing, IT, Industry 4.0, COVID-19 pandemic

Abstrakt. W świecie szybko postępującej digitalizacji oraz cyfryzacji i związanych z tym udogodnień organizacje rozpoczęły przenoszenie swojej działalności do sfery cyfrowej. Pozwoliło to na utworzenie nowej koncepcji - Przemysłu 4.0, której głównym założeniem jest usieciowienie wszystkich czynności zachodzących w przedsiębiorstwach. Główną rolę w tym procesie odgrywać będzie możliwość wirtualizacji (np. sprzętu komputerowego) i dostęp do niego z dowolnego miejsca o dowolnym czasie przez interesariuszy (klientów, pracowników oraz inne podmioty zewnętrzne) za pomocą zintegrowanego środowiska zapewniającego odpowiednią moc obliczeniową (chmura obliczeniowa). Zjawisko to będzie generować nowe rozwiązania techniczno-technologiczne na polu szeroko pojętej automatyzacji procesów zarządzania. Poruszana problematyka znajduje szczególne zastosowanie podczas występowania różnego rodzaju zagrożeń (zewnętrznych oraz wewnętrznych), których powstawanie prowadzi do niemożności fizycznego (osobistego) prowadzenia działalności gospodarczej. Jest to szczególnie widoczne na kanwie ostatnich wydarzeń związanych z wystąpieniem pandemii koronawirusa (SARS-CoV-2), która wymusiła na wielu podmiotach (prywatnych oraz publicznych) przejście na model pracy zdalnej. By spełnił on swój podstawowy cel - zapewnienie ciągłości działania podmiotu - zostały utworzone nowe oraz rozbudowane już istniejące narzędzia wspomagające pracę zdalną, które oparte są również na wirtualizacji zasobów sprzętowych oraz chmurze obliczeniowej. By obniżyć poziom ryzyka, który wzrósł ze względu na konieczność szybkiego dostosowania procesów zachodzących w organizacjach do formuły pracy zdalnej (zwiększone występowanie cyberzagrożeń), koniecznym staje się wykonanie analizy dostępnych rozwiązań narzędziowych w celu przygotowania odpowiednich rekomendacji (dobrych praktyk) możliwych do wdrożenia w każdym podmiocie (organizacji) publicznym lub prywatnym. W tym celu należy dokonać analizy danych zastanych (desk research) oraz przeglądu dostępnej literatury przedmiotu (w tym również dostępnej dokumentacji technicznej), by uzyskać katalog efektywnych rozwiązań techniczno-organizacyjnych.

Słowa kluczowe: wirtualizacja, chmura obliczeniowa, IT, Przemysł 4.0, pandemia COVID-19

\section{Introduction}

In an economy strongly based on data and information and the knowledge gained from them, it becomes necessary to follow modern (contemporary) trends in the field of digitalization and digitization of organizational processes. The use of newly created technical and technological solutions will support their optimization by increasing the effectiveness of the activities of individual units (people). Ignoring the IT sphere in the activities of enterprises will have long-term consequences (e.g. lowering the efficiency of production processes), which will affect not only the organization itself, but also entities cooperating with it. It should be noted, however, that negligence in the above-mentioned domain may result not only from the reluctance of decision-makers or the shortage of qualified staff (human factor), but also from the lack of appropriate material or financial resources (material factor).

Two well-scalable solutions can be used to reduce the negative impact of the deficit of the available pool of material and human resources in the implementation of IT solutions - cloud computing and virtualization. They allow access to computer 
hardware and software without having to physically purchase them. The terms of use of the above-mentioned solutions is to have an appropriate connection to the Internet (speed) and computers intended for office work with the ability to support a web browser. Most of the services provided are based on the more and more widely used web applications, which allow for a wider range of activities with regard to the functionalities offered by websites, which mainly fulfill information functions. The service is provided by qualified employees of the supplier of the purchased service, which translates into a reduction in the level of costs of running a business. As can be seen, cloud computing and virtualization can significantly support organizational processes.

\section{Industry 4.0}

Over the years, organizational management paradigms have been completely reevaluated. This is related to the constantly progressing technical and technological development, which allows to give a new quality to already known processes, e.g. production, with the use of new tools that will serve to improve them or distinguish completely new ones (ICT management). On the basis of these changes, we can distinguish three important milestones that have had a significant impact on the administration of enterprises (Piątek, 2017):

1. Mechanization (Industry 1.0) - implementation of steam engines for general use, beginning of industrialization;

2. Electrification (Industry 2.0) - emergence of production lines, increasing production capacity (serialization);

3. Digitization (Industry 3.0) - informatization and computerization of management processes.

The changes introduced by them intensified the development of the industry, which allowed for a significant increase in the volume of not only manufactured items or services, but also data and resulting information.

Attempts to use the generated data have led to the formation of a new business management model - Industry 4.0, which owes its core to the constantly progressing digitization that forms the basis of Industry 3.0. It can be defined as a complex process of technological transformation that affects the ways of managing organizations, focusing on networking processes and increasing the digitization of products and services, which leads to an increase in the automation of enterprises (Przemyst dla przyszłości, 2021).

Networking of processes will support access to information between various branches of the organization (own or cooperating). They will be available at any time, from anywhere with access to the Internet. This will lead to an increase in 
the level of their effectiveness. Increasing the efficiency of the activities carried out will translate into increasing the competitiveness of a given enterprise on local and global markets. Digitization and the related digitalization will additionally affect the competitiveness of the organization and will result in more economic use of the available material and human resources.

\section{Virtualization and cloud computing}

Virtualization is a simulation of a real computer environment that allows you to run multiple instances of different operating systems as if they were separate machines (Serafin, 2012, p. 13). The following virtualization techniques can be distinguished (Serafin, 2012, pp. 13-15):

1. Full hardware emulation - all computer hardware is emulated;

2. Full virtualization - full access to hardware resources for the guest system using virtualization software as an intermediary;

3. Hardware virtualization - execution of instructions from the guest system directly on the physical hardware;

4. Paravirtualization - adding an additional abstraction layer between the guest and the host system;

5. Virtualization with the use of a common kernel - the ability to run many of the same operating systems running on the same kernel simultaneously;

6. API emulation - emulation of the application interface.

They allow for matching appropriate programming solutions to the goals set by decision-makers in a given type of organization. The combination of these two tools (software and virtualization) will lead to the creation of a coherent solution that will support the digital transformation of enterprises. They will also be the basis for the creation of cloud computing.

Cloud computing is a kind of computing environment that is based on five principles (Mateos, Rosenberg, 2011, p. 27):

1. Pool of computing resources;

2. Virtualization of computing resources;

3. Flexible scaling;

4. Automatic creation or deletion of virtual machines;

5. Charging only for the resources used.

The first one states that to talk about cloud computing, it is necessary to provide appropriate hardware resources, which may also be located outside the home organization and are available to all users who register for a given service (Mateos, Rosenberg, 2011, p. 28). According to the second principle, they can be virtualized, i.e. the physical hardware (e.g. server) is divided into smaller units constituting separate bodies (computers, servers, applications) (Mateos, Rosenberg, 2011, p. 29). 
Due to the addition of a certain layer of abstraction - the hardware only exists virtually - the process of scaling the computing power has been simplified, because the hardware does not require physical maintenance (e.g. replacement of RAM memory). The entire process takes place with the help of software for creating virtual machines and can take place practically in real time, which allows for a dynamic change (increase or decrease) of the computing power required at a given moment (Mateos, Rosenberg, 2011, p. 30). Using the above-mentioned software, it is also possible to automate service activities, in particular the creation and removal of computing units, which leads to compliance with the fourth principle (Mateos, Rosenberg, 2011, p. 30). The biggest advantage of cloud computing, however, is the economical use of allocated resources. The entity using this solution pays only for the computing resources used, without incurring costs, e.g. for the purchase of appropriate software or hardware resources (rule number five) (Mateos, Rosenberg, 2011, p. 31).

We can distinguish four types of cloud computing. Each of them will be used for different purposes. The public cloud will provide access to highly scalable resources that will be available to everyone (most often after the conclusion of an appropriate agreement) (Dziembek, Bajdor, 2018, p. 30). A private cloud is limited to resources owned by an enterprise and is most often dedicated only to its employees (Dziembek, Bajdor, 2018, p. 30). Hybrid cloud is a combination of the above solutions, combining their best features - security and efficiency (Dziembek, Bajdor, 2018, p. 30). A quite unusual type of cloud computing is a community cloud, which is a type of private cloud limited to a closed group of users (e.g. from several organizations) (Dziembek, Bajdor, 2018, p. 30).

The choice of appropriate tool solutions will be primarily determined by economic factors. This will be especially visible through the prism of events caused by the coronavirus pandemic. Many companies have been forced to switch to remote work with a significant reduction in the inflow of new funds.

\section{The use of virtualization and cloud computing to support organization management in the reality of Industry 4.0}

Recent events caused by the COVID-19 pandemic have led to a rapid increase in the introduction of IT solutions for use in organizations due to the need to switch to remote work. This trend is also noticeable in the case of the use of cloud computing. In 2020, as many as $24.4 \%$ of all enterprises in Poland used them. This is an increase by $6.9 \%$ compared to 2019 , where only $17.5 \%$ of all organizations used this tool (see fig. 1).

Considering the size of the enterprise, cloud solutions have gained the greatest popularity in large organizations. When analyzing the results made available by the 
Central Statistical Office of Poland (GUS), it can be noticed that the largest increase was recorded in entities from the sector dealing with broadly understood information and communication (63.5\%). The least interest in the above-mentioned technology can be seen in small businesses and in the accommodation and catering industry, respectively $20.6 \%$ and $15.2 \%$.

Compared to the entire European Union, Poland is in the pre penultimate place in the use of paid cloud-based solutions (see fig. 2). The average in the European Union is $24 \%$, and Finland can boast the highest percentage of the use of paid cloud solutions $(65 \%)$.

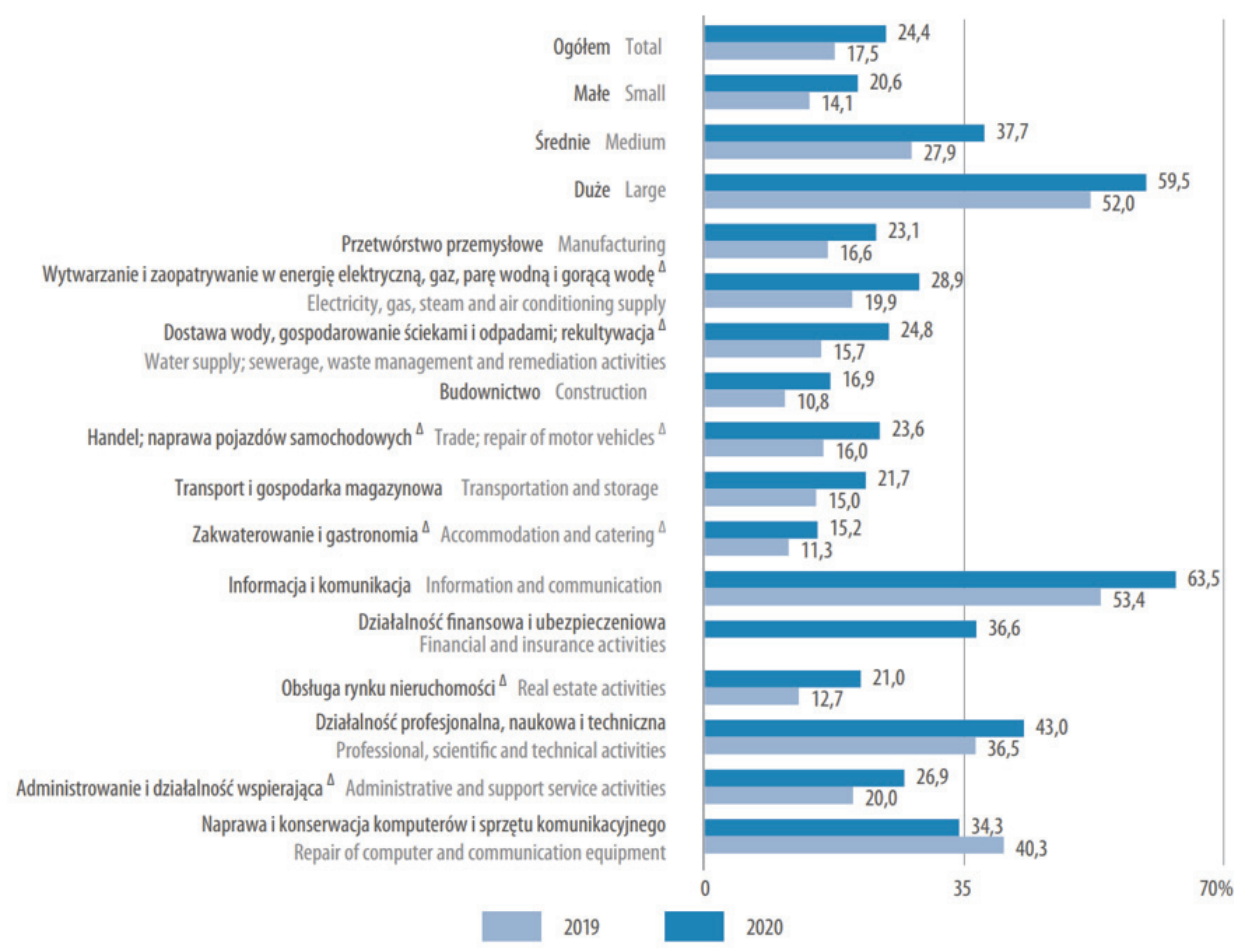

Fig. 1. The use of paid cloud computing services by enterprises

Source: GUS, 2020, p. 99

Analyzing the above data, it can be seen that cloud computing and the solutions it offers are becoming more and more popular not only in the local but also in the global context. It can therefore be predicted that in the future the percentage of companies using this technology will increase. Increasing this level will result in an increasing use of tool solutions based on cloud computing. 


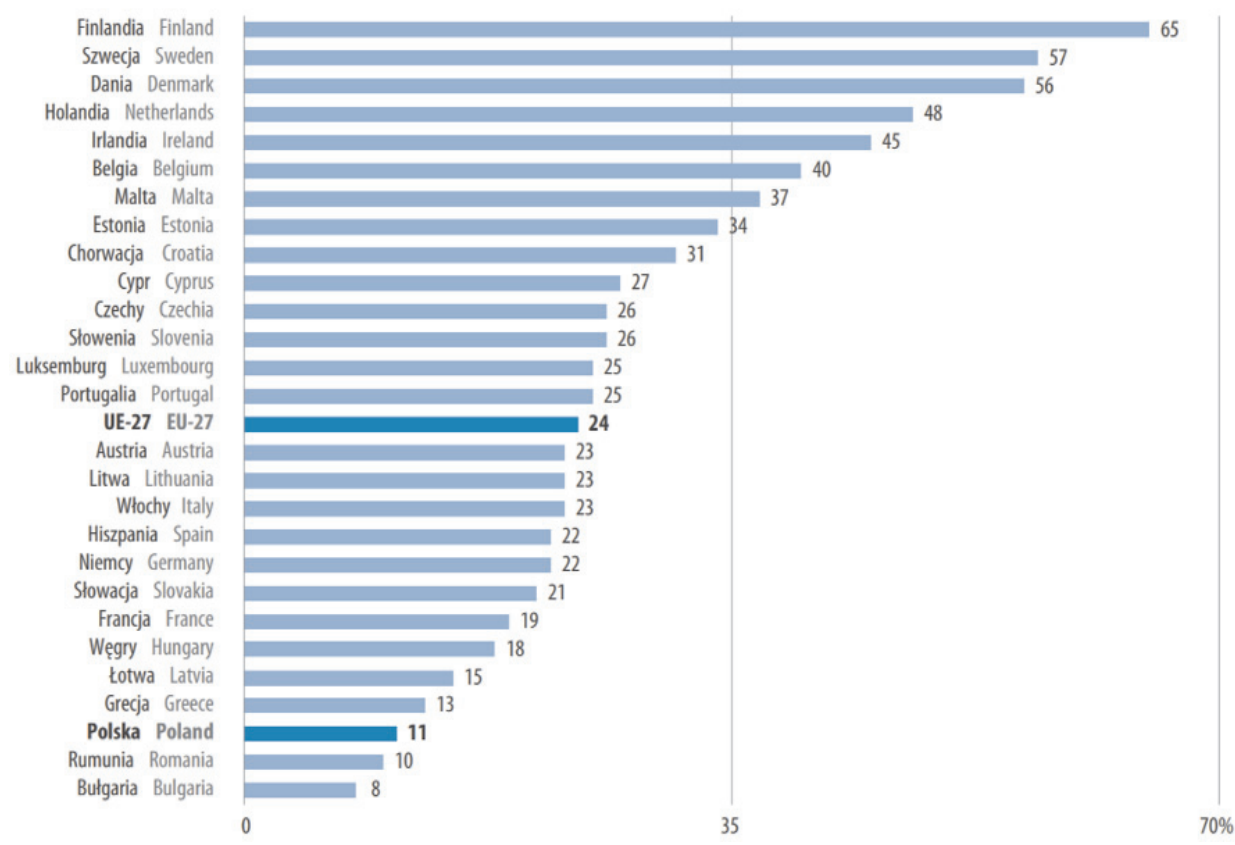

Fig. 2. Enterprises using Cloud computing services in European Union countries in 2018 Source: GUS, 2020, p. 100

Analyzing the above data, it can be seen that cloud computing and the solutions it offers are becoming more and more popular not only in the local but also in the global context. It can therefore be predicted that in the future the percentage of companies using this technology will increase. Increasing this level will result in an increasing use of tool solutions based on cloud computing.

The Industry 4.0 phenomenon, due to its orientation towards automation, will lead to the emergence of an increasing number of autonomous systems (e.g. intelligent warehouses), the task of which is to improve the efficiency of the processes taking place in the enterprise and minimize the possibility of a threat (error). The use of cloud computing and the related virtualization for their construction will allow for the integration of the hardware (virtual) layer with physical activities. It will be possible thanks to the use of supporting solutions that are based on cloud computing (e.g. Internet of Things or Artificial Intelligence). They will allow for uninterrupted exchange of information in real time between the company's branches and subcontractors, for example about available resources by downloading and analyzing data from intelligent tools, sensors or even smartphones. The results of this analysis will provide power to Big Data systems that will acquire new knowledge from the data held. 
To perform their operations, they will use the computing power flowing from a properly scaled cloud. The knowledge obtained in this way will support, for example, enterprise reorganization processes, the implementation of which will imply the need to implement new or supplement the currently used IT solutions (e.g. Integrated IT Management Systems). Automating e.g. the knowledge acquisition or production cycle will also translate into the possibility of a more flexible response to changing market conditions and better adaptation of your products or services to the customer profile. Due to the generation of large volumes of data, cloud computing will also support ensuring the security of data processed in the organization's IT systems by providing adequate computing power to perform heuristic analysis in order to detect previously unknown threats, including physical threats, such as e.g. damage to production machines. Data security will also be enhanced by the use of a double layer of security, which will be provided by the service provider (coherent with the service provided) and the recipient (complementing the received service). The scalability of cloud solutions will lead to a reduction in the cost of automation processes due to the ability to adjust the computing power of selected systems to the current level of demand for it. This will reduce the fixed costs incurred by organizations (e.g. for electricity), because the systems will be used only when it is necessary to use them.

\section{Conclusions}

In the era of rapidly progressing technical and technological development and the related phenomenon of digitization and digitalization, it becomes necessary to use newly developed tools to ensure competitiveness in local and global markets by organizations. Cloud computing and the related virtualization of hardware resources are the most widely used to achieve this goal. These tools will support or even completely automate the processes taking place in enterprises in accordance with the assumptions of the Industry 4.0 paradigm.

The use of cloud solutions will lead to an increase in the efficiency of organizational processes. It will also allow to increase the level of security of the processed information. It will also ensure an increase in the level of compliance with the current legal regulations and standards voluntarily adopted by the organization. As can be seen, the implementation and use of cloud computing and related virtualization will bring tangible benefits for the organization, e.g. in the form of additional financial resources. However, the quality of the implemented tools should be constantly monitored so that in the event of an error, it is possible to correct it as soon as possible, because its occurrence may have a negative impact on the efficiency of the organization, and even result in interrupting its continuity of operation. 


\section{REFERENCES}

[1] Dziembek, D, Bajdor, P., 2018. Wykorzystanie chmury obliczeniowej w przedsiębiorstwach - wstępne wyniki badań, Studia Ekonomiczne. Zeszyty Naukowe Uniwersytetu Ekonomicznego w Katowicach, No. 368(18).

[2] GUS, 2020. Społeczeństwo informacyjne w Polsce w 2020 roku, Główny Urząd Statystyczny, https://stat.gov.pl/download/gfx/portalinformacyjny/pl/defaultaktualnosci/5497/1/14/1/spoleczenstwo_informacyjne_w_polsce_w_2020_r..pdf (15.04.2021).

[3] Mateos, A., Rosenberg, J., 2011. Chmura obliczeniowa. Rozwiązania dla biznesu, Gliwice: Helion.

[4] Piątek, Z., 2017. Czym jest Przemysł 4.0? - część 1, Industry 4.0 - Portal nowoczesnego przemysłu, https://przemysl-40.pl/index.php/2017/03/22/czym-jest-przemysl-4-0/ (15.04.2021).

[5] Przemysł dla przyszłości, 2021. https://przemyslprzyszlosci.gov.pl/tag/przemysl-4-0/\#desc-bottom (2.04.2021).

[6] Serafin, M., 2012. Wirtualizacja w praktyce, Gliwice: Helion. 
